\title{
Principals' and Teachers' Practices about Parent Involvement in Schooling ${ }^{* i}$
}

\author{
Mehmet Akif Erdener \\ Faculty of Necatibey Education, Balıkesir University, Turkey
}

Copyright $(2016$ by authors, all rights reserved. Authors agree that this article remains permanently open access under the terms of the Creative Commons Attribution License 4.0 International License

\begin{abstract}
Parent involvement has an influence on children's educational engagement for all school levels. The objective of this study was to examine public school principals' and teachers' practices for improving parent involvement in schooling. This study used a mixed method to identify the school administrators' and teachers' perceptions about parent involvement in schooling. Data was collected from 64 public schools' administrators and teachers of elementary, middle and high schools. Six hundred and sixty one $(55 \%)$ of surveys returned from 28 elementary schools, 27 middle schools, and 9 high schools. Data was analyzed with Confirmatory Factor Analysis (CFA) and Multivariate Analysis of Variance (MANOVA) using the Statistical Package for Social Sciences (SPSS). For qualitative part, phenomenological research method was used to investigate principals' and teachers' experiences to promote parent involvement. Findings indicated that school levels and teachers' education levels had a statistically significant impact on combined factors of parent involvement. No significant differences were found in parent involvement among principals and teachers who are from different major, gender, and seniority groups. This study showed that educator' attitudes is the most significant factor on parental involvement in schooling. Additionally, this study claimed when principals offer different time schedule for parent and teacher meetings, parent involvement is increased. One of parents is selected by Parent Teacher Organization for each grade so parents might use social media for all of meetings, offers, events, and announcements.
\end{abstract}

Keywords Parent Involvement, Teacher Attitudes, Schooling, Principals' Practices

\section{Introduction}

Educational researchers have been interested in how parental involvement affects on students' academic achievement and success [23]. Studies have shown that parent involvement increases students' academic achievement and self-esteem [12,25] while decreasing absenteeism and behavioral problems [21,33]. Children learn from their families, teachers, peers, relatives, part-time employers, and other adults in the community, so relationship among home, school, and community are very significant [17]. Michael et al., [33] said that if family and community involve in schooling, students' academic achievement and school attendance might increase, and it improves school programs and quality.

Epstein [17] clarified the following points: 1) many parents need more information from schools to be productively involved in their children's education; 2) learning at home, at school, and in the community is very important for students; 3) peers, families, and the organization of activities in schools and classrooms promote students achievement positively or negatively; and 4) community-based programs might be supported to increase home, school and the community collaboration. Principal, teachers, school council and parents who are accountable for their plans and work might design these activities [17]. Epstein conducted research over several decades using a model of parent involvement $[14,15]$. She categorized parent involvement into six major types: (1) parenting, (2) communicating, (3) volunteering, (4) learning at home, (5) decision making, and (6) collaborating with the community.

Parenting is to have information about student needs and interests, as well as families' responsibilities for child growth and development [20]. Communicating is to increase two way communications from home to school and from school to home in order to develop understanding and cooperation between school and home [20]. Volunteering is that parents share their time and talents to help schools, teachers, and students. They might assist schools in the library, playground, and cafeteria for after school activities, celebrations, sport activities and other events [20]. Learning at home activities guide parents to help their children for homework and prepare a study field at home [20]. Decision Making is that parents involve in the decision making process about school programs, activities, support students for post-secondary school selection [20]. Collaborating with the community is 
to help cooperation among schools, families, organizations, community groups, and agencies [20].

Parents' demographic characteristics and parent involvement directly affect student achievement in schooling $[1,7,8,10,13,19,27,38]$. Rosenberg and Lopez [35] claimed that families support children's learning and growth from cradle to career. Many studies have investigated how parental involvement affects student achievement. In addition, many studies carried out that school administrators and teachers need to provide parent involvement.

However, investigations about educators practices and attitudes towards to parent to increase their involvement in schooling is minimal in Turkey. Erdener[24] said that the extant knowledge about cultural influences on Turkish parents' perceptions of their involvement in schooling is limited. In his previous study, parents said that teachers' attitudes affect their involvement, and teachers might guide parents how to involve their children schooling. Therefore, this study analyzed school administrators and teachers practices about parent involvement in schooling.

Many studies have shown that parent involvement in schooling affect students' academic achievement $[16,17]$. Determining the effective level of parent involvement may be associated with educators' attitudes. The primary purpose of this study was to investigate what public school principals' and teachers' practices for improving parent involvement in schooling in Turkey. The second purpose of this study was to explore which school level parent involvement is appropriate in schooling. Thirdly, this study examined the differences of teachers' attitudes among their major (administrators, early childhood and elementary teachers, science, and social science) about parent involvement in Turkey. Understanding principals' and teachers' perceptions about parent involvement may help to see the weaknesses and strengths of the relationship among home, school, and the community. Therefore, school administrators and teachers may more effectively promote parent involvement in schooling. For this purpose, the following problems and sub-problems were questioned:

- What is the difference among principals' and teachers' perceptions when grouped their education level, seniority, major, gender and school level on Epstein's six factors of parent involvement as described (parenting, communicating, volunteering, learning at home, decision making, and collaborating with the community) in public schools?

- What major factors contributed or limited to the success of your school's parental involvement?

- What are the practices of principals and teacher about parent involvement?

One of the key components for students' academic success is parent involvement in education [24]. Many studies claimed that there is a positive correlation between parental involvement and student achievement $[17,31,36]$. The significance of this study was to examine the perceptions of school principals and teachers regarding effective parental involvement in public schools based on Epstein's [16] six types of parental involvement. Therefore, this study's results may indicate more effective means of parental involvement for practices of principal and teachers in schooling progress. The findings of this study provided significant information that will extend knowledge about the phenomenon of parent involvement in Turkey.

Bronfenbrenner's Bioecoloogical theory and Epstein's Overlapping Spheres theory drove this study. Bronfenbrenner [3] stated that the changing environment affects human development. Bioecological Theory [3,4] included five systems: 1) Microsystems, 2) Mesosystem, 3) Exosystem, 4) Macrosystem, and 5) Chronosystem [3,4]. The child is at the center of the systems and each system directly and indirectly affects the learning of individuals. The relationship existing between the family and the school is a powerful factor affecting the capacity of a child to learn in the classroom [4]. One of the processes of child development in social and educational environments is parent involvement. Furthermore, Epstein's [18] overlapping spheres of influence model demonstrates the relationships of the school, family, and community about child development. Epstein [18] said that the child is at the center as the focus within the family, school, and community. Child has interactions with his/her families, schools, and the communities [16]. Families, schools, and the communities influence a child's academic achievement and success[16], and each component of the external structure of the overlapping spheres also might act and interact with others so these actions influence student learning and development [18].

\section{Method}

\subsection{Instrument}

This research study used a mixed method to identify the school administrators' and teachers' perceptions about parent involvement in schooling. The researcher adapted a survey that is developed by Epstein et al. ([20], p. 324-329). The survey included Epstein's six categories of parental involvement with an additional category of the school administrators' and teachers' expectations. The survey contained 51 parent involvement statements distributed among six categories of parental involvement. The survey questions were based on 5-point Likert scale for perceptions ranging from a low score of 1 (never) to a high score of 5 (frequently). Additionally, the instrument included a section on participants' demographic information. This section helped the researcher investigate the differences between teachers' school level, majors, seniority, education level, and gender and their perceptions about parent involvement as measured by Epstein's model of parent involvement.

\subsection{Participants}

The targeted populations in this study were public school 
administrators and teachers of elementary, middle and high schools in Turkey. One thousands and two hundred paper copies of survey were sent to 64 public schools. Six hundred and sixty one $(55 \%)$ of surveys returned to the researcher. Two hundred thirty three $(35.2 \%)$ participants were from 28 elementary schools, two hundred sixty (39.3\%) participants were from 27 middle schools, and one hundred sixty eight (25.4\%) participants were from 9 high schools in the city of Bursa, Turkey. Participants were not required to provide any identifying information. The anonymity of the subjects strengthens the validity of the instrument and the study. The means and standard deviations of participants demographic are represented in Table 1.

In this study, there were three hundred and forty two (51.7\%) male participants and three hundred and five (46.1) female participants. Nevertheless, fourteen $(2.1 \%)$ participants did not specify their gender. Sixty four $(9.7 \%)$ participants had some college degrees, 567 (85.8\%) participants had bachelor's degrees, and $30 \quad(4.5 \%)$ participants had graduate degrees. One hundred sixty three (24.7\%) participants have taught between 0-5 years; one hundred and twenty (18.2\%) participants have taught between 5-10 years; one hundred thirty one (19.8\%) participants have taught between 10-20 years; one hundred and fifteen (17.4\%) participants have taught between 20-25 years; and one hundred and thirteen (17.1\%) participants have taught between 26 and more years. Nineteen $(2.9 \%)$ participants did not state about their seniority. Seventy seven (11.6\%) participants were school administrators; one hundred and twenty four (18.8\%) participants were social science teachers; two hundred and fifteen $(32.5 \%)$ participants were early childhood and elementary teachers; one hundred seven (16.2\%) participants were science teachers; and one hundred twenty seven (19.2\%) participants were teaching other courses. Nevertheless, eleven $(1.7 \%)$ participants did not explain their majors.

\subsection{Data Analysis}

After surveys were returned, qualitative data analysis followed. Qualitative data were analyzed using the Lisrel 8.5 to conduct Confirmatory Factor Analysis (CFA) and using the Statistical Package for Social Sciences (SPSS) [37] to conduct Multivariate Analysis of Variance (MANOVA). Factor analysis provided the researcher with the ability to reduce and cluster the complexity of the variables, so it was easier for the researcher to investigate the question [30,32]. Mertler and Vannaatta [32] said that confirmatory factor analysis is usually applied to test a theory about latent processes that might occur among variables. As such, Davidov and Beuckelaer [11] suggested that the researcher needed to evaluate the reliability of the survey instrument. There were six dependent and five independent variables in this study, so MANOVA included many dependent variables in the same analysis [26] and incorporated two or more dependent variables in the same analysis with nominal and ordinal independent variables [32]. For qualitative part, phenomenological research method was used to investigate principals' and teachers' experiences to promote parent involvement. Phenomenological research emphasizes a focus on participants' subjective experiences and interpretations about phenomena[6]. The authors clarified that primary goal of phenomenological research method is to return to embodied, and experiential meanings of participants.

\section{Results}

The data were collected from 661 elementary, middle and high school teachers in Turkey. Confirmatory factor analysis was to confirm Epstein's survey that explains the six types of parental involvement factors by using LISREL 8.5 that is the analytical computer program. Cronbach's alpha was used to check the reliability of the study; the reliability was 0.968 of 51 items. After Confirmatory Factor Analysis was conducted, the factors were determined according to Epstein's typology labels. Factor 1 was labeled Parenting, and contained seven items. The reliability of the Parenting factor was 0.841 of 7 items by using Cronbach's alpha. Factor 2 was labeled the Communicating, and contained fourteen items. The reliability of Communicating factor was 0.880 of 14 items. Factor 3 was labeled the Volunteering, and contained eight items. The reliability of the Volunteering factor was 0.890 of 8 items. Factor 4 was labeled the Learning at Home and contained seven items. The reliability of the Learning at Home factor was 0.898 of 7 items. Factor 5 was labeled the Decision Making, and contained eleven items. The reliability of the Decision Making factor was 0.891 of 11 items. The last factor was labeled the Collaborating with the Community and contained four items. The reliability of the Collaborating with the Community factor was 0.880 of 4 items.

Büyüköztürk, Şekercioğlu and Çokluk [5] described that factor analysis patterns factors by using existing model and variables. There are different good fit indexes about the decision of the good fit indexes of models. For this indexes, the values are excellent and acceptable ([2,29,39]). The figure of the survey's confirmatory factor analysis is shown in Figure 1 and the results of the survey's confirmatory factor analysis are shown in Table 2. 
Table 1. Participants' Demographic

\begin{tabular}{|c|c|c|c|c|c|c|}
\hline & & School & Major & Gender & Education Level & Seniority \\
\hline \multirow{2}{*}{$\mathrm{N}$} & Valid & 661 & 650 & 647 & 661 & 642 \\
\hline & Missing & 0 & 11 & 14 & 0 & 19 \\
\hline \multicolumn{2}{|c|}{ Mean } & 1.90 & 3.13 & 1.47 & 1.95 & 2.84 \\
\hline \multicolumn{2}{|c|}{ SE of Mean } & .030 & .050 & .020 & .015 & .057 \\
\hline \multicolumn{2}{|c|}{ Median } & 2.00 & 3.00 & 1.00 & 2.00 & 3.00 \\
\hline \multicolumn{2}{|c|}{ Mode } & 2 & 3 & 1 & 2 & 1 \\
\hline \multicolumn{2}{|c|}{$\mathrm{SD}$} & .773 & 1.264 & .500 & .374 & 1.436 \\
\hline \multicolumn{2}{|c|}{ Variance } & .598 & 1.597 & .250 & .140 & 2.062 \\
\hline \multicolumn{2}{|c|}{ Minimum } & 1 & 1 & 1 & 1 & 1 \\
\hline \multicolumn{2}{|c|}{ Maximum } & 3 & 5 & 2 & 3 & 5 \\
\hline \multicolumn{2}{|c|}{ Sum } & 1257 & 2033 & 952 & 1288 & 1821 \\
\hline
\end{tabular}

Table 2. Confirmatory Factor Analysis Good Fit Indexes

\begin{tabular}{cccc}
\hline & Good fit Values & Results & Decision \\
\hline$\chi^{2}$ & & 3265.97 & \\
$\mathrm{sd}$ & $<3=$ Excellent & 1139 & Accepted \\
$\chi^{2} / \mathrm{sd}$ & $>.95=$ Excellent & 2.867 & Acceptable \\
GFI & $>.90($ AGFI).95<= Good fit & 0.84 & Acceptable \\
AGFI & $>.95=$ Excellent & 0.81 & Accepted \\
CFI & $>.95=$ Excellent & 0.99 & Accepted \\
NFI & $>.95=$ Excellent & 0.98 & Accepted \\
NNFI & $<.05=$ Excellent & 0.99 & Accepted \\
SRMR & $>.05=$ RMR $<.081=$ Good fit & 0.057 & Accepted \\
RMR & $<.05=$ Excellent & 0.067 & Accepted \\
RMSEA & $>.95=$ Excellent & 0.053 & Accepted \\
RFI & $>.95=$ Excellent & 0.98 & Accepted \\
IFI & & 0.99 & \\
\hline
\end{tabular}




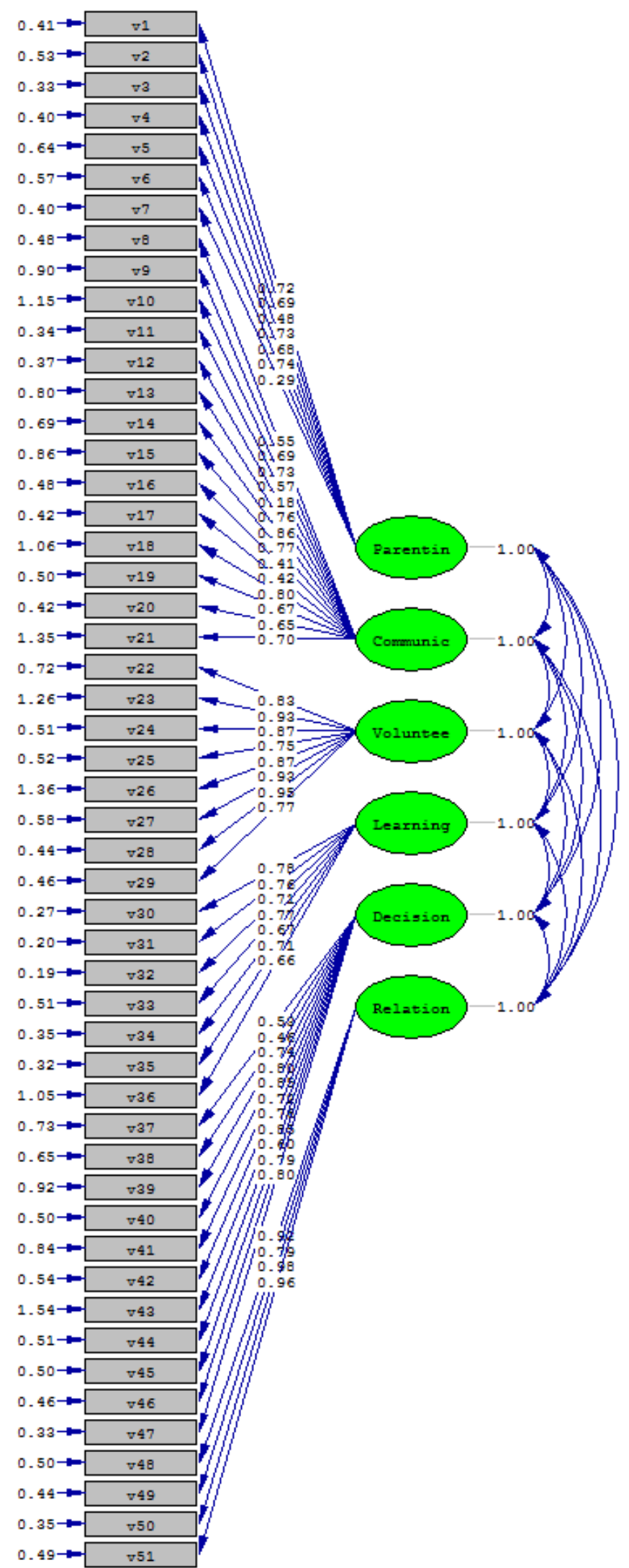

Chi-Square $=3265.97, \mathrm{df}=1139, \mathrm{P}-\mathrm{value}=0.00000, \mathrm{RMSEA}=0.053$

Figure 1. The Path Diagram of Parent Involvement Model 
Confirmatory Factor Analysis (CFA) presented that the results of the values for good fit indexes of parent involvement survey were excellent or acceptable. According to the good fit indexes, the model is practical. Then, the full Multivariate Analysis of Variance (MANOVA) was conducted. The output interpretations begin with the results of Box's test [32]. The results of the Box's test of equality of variance, $F(588,15479.3)=1.158, p=0.006$. The Box's test was significant and the groups were unequal, so the Pillai's Trace was chosen. A violation of this assumption of homoscedasticity will not prove fatal to analysis; despite this, a more robust multivariate test statistics, Pillai's Trace, was used to interpret the multivariate results [32].

The results of the multivariate test of the perceptions of school administrators and teachers about parent involvement indicated that school level [Pillai's Trace $=0.054, \mathrm{~F}(12,994)$ $=2.316, p=0.006$, partial $\eta 2=0.027]$ is significantly affecting the combined dependent variables of Parenting, Communicating, Volunteering, Learning at Home, Decision-Making, and Collaborating with the Community. Education level of participants [Pillai's Trace $=0.043, \mathrm{~F}(12$, $994)=1.810, p=0.042$, partial $\eta 2=0.021]$ is significantly affecting the combined dependent variables of Parenting, Communicating, Volunteering, Learning at Home, Decision-Making, and Collaborating with the Community. Education level by Gender interaction [Pillai's Trace $=0.06$, $\mathrm{F}(12,994)=2.541, \mathrm{p}=0.003$, partial $\eta 2=0.030]$ is significantly affecting the combined dependent variables of Parent Involvement. Education level by Seniority interaction [Pillai's Trace $=0.087, \mathrm{~F}(30,2500)=1.473, \mathrm{p}=0.047$, partial $\eta 2=0.017$ ] is significantly affecting the combined dependent variables of Parent Involvement. Major by Gender by Seniority interaction [Pillai's Trace $=0.190, \mathrm{~F}(66$, $3006)=1.489, p=0.007$, partial $\eta 2=0.032]$ is significantly affecting the combined dependent variables of Parent Involvement. Major, Gender, and Seniority do not statistically affect the combined dependent variables of Parenting, Communicating, Volunteering, Learning at Home, Decision-Making, and Collaborating with the Community. The results of multivariate test of the perceptions of school administrators and teachers about parent involvement are presented in Table 3.
A Univariate Analysis of Variance (ANOVA) was conducted as a follow-up test. Education by Gender interaction $F(5,501)=4.483, p=0.012$, significantly affects the Parenting. A post-hoc analysis was conducted using the Tukey procedure, to determine where the differences were within the parent involvement factors for education level and school level of public school administrators and teachers. Post-hoc test compare significant differences between the high school level, middle school level and elementary school level on parenting, communicating, volunteering, learning at home, decision-making and the community collaboration. There are no significant differences between the high school level, middle school level and elementary school level on parenting, and decision-making. Nevertheless, communicating of parent involvement scores is higher on high school administrators and teachers than middle school and elementary school administrators and teachers. Moreover, volunteering and learning at home of parent involvement scores is higher on elementary school administrators and teachers than middle school administrators and teachers and also volunteering is higher on middle school administrators and teachers than high school administrators and teachers. Furthermore, the post hoc comparison yielded a significant difference between high school level, middle school level and elementary school level, with the community collaboration scoring higher on high school administrators and teachers than middle school and elementary school administrators and teachers.

There are no significant differences between the education level of school administrators and teachers on parenting, and learning at home. In addition, the post hoc comparison yielded a significant difference between the education level of school administrators and teachers, with the communicating, volunteering, and decision-making scores higher on school administrators and teachers who have some college degrees than school administrators and teachers who have Bachelor's degrees. Furthermore, communicating, and the collaboration with community of parent involvement scores is higher on school administrators and teachers who have Master's degrees than school administrators and teachers who have Bachelor's degrees.

Table 3. Multivariate Test

\begin{tabular}{|c|c|c|c|c|c|c|c|c|c|}
\hline \multicolumn{10}{|c|}{ Multivariate Tests ${ }^{\mathrm{a}}$} \\
\hline \multicolumn{2}{|c|}{ Effect } & Value & $\mathrm{F}$ & Hypothesis df & Error df & Sig. & $\begin{array}{c}\text { Partial Eta } \\
\text { Squared }\end{array}$ & $\begin{array}{l}\text { Noncent. } \\
\text { Parameter }\end{array}$ & $\begin{array}{l}\text { Observed } \\
\text { Power }^{\mathrm{d}}\end{array}$ \\
\hline Intercept & Pillai's Trace & .865 & 530.28 & 6.000 & 496.000 & .000 & .865 & 3181.679 & 1.000 \\
\hline School & Pillai's Trace & .054 & 2.316 & 12.000 & 994.000 & .006 & .027 & 27.795 & .963 \\
\hline Major & Pillai's Trace & .055 & 1.160 & 24.000 & 1996.000 & .268 & .014 & 27.842 & .895 \\
\hline Gender & Pillai's Trace & .009 & .728 & 6.000 & 496.000 & .627 & .009 & 4.367 & .290 \\
\hline Ed. Level & Pillai's Trace & .043 & 1.810 & 12.000 & 994.000 & .042 & .021 & 21.724 & .894 \\
\hline Seniority & Pillai's Trace & .058 & 1.230 & 24.000 & 1996.000 & .203 & .015 & 29.523 & .917 \\
\hline $\begin{array}{l}\text { Gender* } \\
\text { Ed. Level }\end{array}$ & Pillai's Trace & .060 & 2.541 & 12.000 & 994.000 & .003 & .030 & 30.490 & .978 \\
\hline $\begin{array}{l}\text { Seniority * Ed. } \\
\text { Level }\end{array}$ & Pillai's Trace & .087 & 1.473 & 30.000 & 2500.000 & .047 & .017 & 44.176 & .986 \\
\hline $\begin{array}{l}\text { Major * Gender } \\
\text { * Seniority }\end{array}$ & Pillai's Trace & .190 & 1.489 & 66.000 & 3006.000 & .007 & .032 & 98.286 & 1.000 \\
\hline
\end{tabular}

Note. Computed using alpha $=.05$ 


\section{Conclusion and Discussion}

After Confirmatory Factor Analysis (CFA) was applied, the six factors of parent involvement were confirmed as (1) parenting, (2) communicating (3) volunteering (4) learning at home (5) decision making, and (6) collaborating with the community. Epstein et al.,[20] described the parent involvement factors as the following: parenting is an awareness of every step of child growth and development so parents might be supported with more information from teachers about parenting. In addition, parent should attend school activities as a volunteer to increase relationship with teachers and principals so parents might be a part of the decision-making process for school programs, events and their children career plans. Moreover, teachers might support parents to be aware of their child's talents, skills, and abilities. In this manner, parents monitoring and discussing the schooling process at home with their children.

The six factors were used as dependent variables to conduct the Multivariate Analysis of Variance (MANOVA). The findings indicated that school level and administrators' and teachers' education level significantly affected the combined parent involvement factors of Parenting, Communicating, Volunteering, Learning at Home, Decision-Making, and Collaborating with the community. On the other hand, major, gender and seniority of administrators and teachers did not significantly affect the combined dependent variables of Parenting, Communicating, Volunteering, Learning at Home, Decision-Making, and Collaborating with the community. Child's cognitive development and academic achievement are affected by parents[28].

The interaction between education level and gender significantly affected the combined dependent variables of parent involvement. Also, the interaction between seniority and education level significantly affected the combined dependent variables of parent involvement. In addition, the interaction among major, gender and seniority significantly affected the combined dependent variables of parent involvement. Moreover, the results of the follow-up test, the Univariate Analysis of Variance (ANOVA), indicated that the interaction between gender and education level of independent variables affected the Parenting factor. The profile of plot is also going be presented about the significant the interaction between gender and education level on parenting factor. According to the plot, female teachers who have some college degrees and male teachers who have masters and doctoral degrees are more likely effective on parenting of parent involvement factors.

According to Creswell [9], qualitative research method focuses on an essential phenomenon and is established via participants' perceptions. Yıldırım and Şimşek [40] said that data analysis in phenomenological study represent participants' background and experiences. In this study, quantitative questionary was not enough to explore the perspectives of principals and teachers about parent involvement, so it was supported by qualitative part with phenomenological research questions. According to principals and teachers, the primary factors which contribute parent involvement are parent education level, parents' perspectives about schooling, students' choice of profession, teachers' attitudes and willingness about collaboration with family, communication, and social \& cultural activities. In addition, participants also emphasized that student achievement, community where family lives, child growth and development, well-educated teachers, communication among family members, income and school community are other factors to increase parent involvement in schooling. Parent education level is highly stressed by principals and teachers. Erdener [24] carried a research out about parent involvement by collecting data from 578 parents and found that educated parents and society affect student achievement because these groups of people have better communication with teachers and principals. They were attending school activities and events. Educated parents are involved in the decision making process about their children's post-secondary education plans, career plans [24].

On the other hand, principals and teachers said that the primary factors which limited parent involvement are low income, parent education level, indifference about schooling, family disturbance, unsuccessful students, teachers' attitudes, heavy workloads of both parents or single parents, and Turkish education system. Moreover, participants explained that intolerance, prejudice of families about school and teachers, social media, and bullying are other factors to limit parent involvement in schooling. Teachers said that income is most important factor for families, because schools budgets are not enough and they need family support to increase education quality. Low income families have to work lots of hours, so they are not involved social events at school. They have not even attended parent-teacher meeting yet. The finding is consistent with previous studies indicated that parents who work in minimum wage jobs and long hours might not be involved in many school activities because they lack the time $[7,25,27,34]$. Turkish education system is changed a few times and some educators think that the changes are not planned very well. The Ministry of National Education is the biggest government department which has more than a million employees and 18 million students. For this reason, the education system might require professional development for the school administrators and teachers about increasing parent involvement in their children's schooling.

Finally, principals and teachers said that they make effort to increase parent involvement. Parent-teacher meetings, home visiting, communication, guide families about schooling and social-cultural activities like reading, drama, celebrating national days, tea hours, and festivals are arranged by schools. Principals sometimes use different time schedule to increase parent attendance. Because, the attendance rate usually is not higher than fifty percent (50\%). Educators stressed parents' guidance to monitor students' activities, growth and development. By the way, teachers make student coaching which are described as to guide 
individual learning methods, abilities and skills for each student. In addition, reading activities with parents and students together help to promote parents willingness for schooling process and increase communication among teacher, parent and student. Principal especially remark the importance of seminars about home, school and the community collaboration.

\section{Note}

*The abstract of this paper was presented at 2nd International Conference on Lifelong Learning and Leadership for All (ICLEL-16), in Liepaja on July, 21-23, 2016.

\section{REFERENCES}

[1] Baroody, A., \& Dobbs-Oates, J. (2009). Child and parent characteristics, parental expectations, and child behaviors related to preschool children's interest in literacy. Early Child Development and Care, 181(3), 345-359.

[2] Bollen, K. A. \& Curran, P. J. (2006). Latent Curve Models: A Structural Equation Perspective. New Jersey, NJ: Wiley-Interscience.

[3] Bronfenbrenner, U. (1977). Toward an experimental ecology of human development. American Psychologist, 32, 513 - 531.

[4] Bronfenbrenner, U. (1986). Ecology of the family as a context for human development: Research perspectives. Developmental Psychology, 22(6), 723 - 742.

[5] Büyüköztürk, Ş., Şekercioğlu, G. \& Çokluk, O. (2014). Sosyal Bilimler Için Çok Değişkenli Istatistik: SPSS ve LISREL Uygulamalart. Ankara: Pegem Akademi Yay.

[6] Büyüköztürk, Ş., Çakmak, E., Akgün, Ö., Karadeniz, Ş. \& Demirel, F. (2015). Bilimsel Araştırma Yöntemleri (17. Bask1). Ankara:Pegem Yayınları

[7] Cooper, C. E. (2010). Family poverty, school-based parental involvement, and policy-focused protective factors in kindergarten. Early Childhood Research Quarterly, 25(4), 480-492.

[8] Cooper, C. E., Crosnoe, R., Suizzo, M. A., \& Pituch, K. A. (2010). Poverty, race, and parental involvement during the transition to elementary school. Journal of Family Issues, 31(7), 859-883. doi: 10.1177/0192513X09351515

[9] Creswell, J. W., (2014). Research Design: Qualitative, Quantitative, and Mixed Methods Approaches (4.th ed.). Los Angeles, SAGE Publications.

[10] Crosnoe, R. (2001). Academic orientation and parental involvement in education during high school. Sociology of Education, 74, 210-230.

[11] Davidov, E., \& Beuckelaer, A. D. (2010). How harmful are survey translations? A test with Schwartz's human values instrument. International Journal of Public Opinion Research, 22(4), 487-510.
[12] Desimone, L. (1999). Linking parent involvement with student achievement: Do race and income matter? The Journal of Educational Research, 93(1), 11-30.

[13] Englund, M. M., Luckner, A. E., Whaley, G. J. L., \& Egeland, B. (2004). Children's achievement in early elementary school: Longitudinal effects of parental involvement, expectations, and quality of assistance. Journal of Educational Psychology, 96, 723-730.

[14] Epstein, J.L. (1985). Home and school connections in schools of the future: Implications of research on parent involvement, Peabody Journal of Education, 62 (2), 18-41. doi: http://dx.doi.org/10.1080/01619568509538471

[15] Epstein, J. L. (1987). Toward a theory of family-school connections: Teacher practices and parent involvement. In K. Hurrelmann, F. Kaufmann, and F. Lösel (Eds.). Social intervention: Potential and constraints, (pp. 121-136). New York: Walter de Gruyter.

[16] Epstein, J. L. (1995). School/family/community partnerships: Caring for the children we share. The Phi Delta Kappan, 76(9), 701-712.

[17] Epstein, J. L. (2001). Building bridges of home, school, and community: The importance of design. Journal of Education for Students Placed at Risk, 6(1/2), 161-168.

[18] Epstein, J. L. (2010). School, family, and community partnerships: Preparing educators and improving schools $\left(2^{\text {nd }}\right.$ ed.). Boulder, CO: Westview Press.

[19] Epstein, J. L., \& Sanders, M. G. (2002). Family, school, and community partnerships. In M. H. Bornstein (Ed.), Handbook of parenting: Vol. 5. Practical issues in parenting (pp. 407-437). Mahwah, NJ: Lawrence Erlbaum.

[20] Epstein, J. L., Sanders, M. G., Sheldon, S. B., Simon, B. S., Salinas, K., Jansorn, N., Van Voorhis, F. L., Martin, C. S., \& Williams, K. J. (2009). School, family, and community partnerships: Your handbook for action (3rd ed.). Thousand Oaks, CA: Corwin Press.

[21] Epstein, J. L., \& Sheldon, S. B. (2002a). Improving student behavior and school discipline with family and community involvement. Education and Urban Society, 35(4), 4-26.

[22] Epstein, J. L., \& Sheldon, S. B. (2002b). Present and accounted for: Improving student attendance through family and community involvement. Journal of Educational Research, 95(5), 308-318.

[23] Erdener, M. A. (2013). Turkish Parents Perceptions of Their Involvement in Schooling. Retrieved from: http://tigerprints.clemson.edu/all_dissertations. (Paper 1153)

[24] Erdener, M. A. (2014). The Factors Which Contribute or Limit Parent Involvement in Schooling. NWSA-Education Sciences, 9(1), 36-47.

[25] Erdoğan, Ç., \& Demirkasımoğlu, N. (2010). Ailelerin eğitim sürecine katılımına ilişkin ögretmen ve yönetici görüşleri [Teachers' and school administrators' views of parent involvement in education process]. Kuram ve Uygulamada Ĕ̈itim Yönetimi [Educational Administration: Theory and Practice], 16(3), 399-431.

[26] Field, A. (2009). Discovering statistics using SPSS. Thousand Oaks, CA: Sage. 
[27] Hill, N. E., Castellino, D. R., Lansford, J. E., Nowlin, P., Dodge, K. A., Bates, J. E. (2004). Parent academic involvement as related to school behavior, achievement, and aspirations: Demographic variations across adolescence. Child Development, 75(5), 1491-1509.

[28] Hortacsu, N. (1995). Parents' education levels, parents' beliefs, and child outcomes. The Journal of Genetic Psychology, 156(3), 373-383.

[29] Hu, L. T. \& Bentler, P. M. (1999). Cutoff Criteria for Fit Indexes in Covariance Structure Analysis: Conventional Criteria Versus New Alternatives. Structural Equation Modeling, 6 (1), 1-55. DOI: 10.1080/10705519909540118.

[30] Huck, S. W. (2011). Reading statistics and research $\left(6^{\text {th }}\right.$ ed.). Boston, MA: Pearson.

[31] Jeynes, W. H. (2005). A meta-analysis of the relation of parental involvement to urban elementary school student academic achievement. Urban Education, 40(3), 237-269. doi:10.1177/0042085905274540

[32] Mertler, C. A., \& Vannaatta, R. A. (2010). Advanced and multivariate statistical methods: Practical application and interpretation $\left(4^{\text {th }}\right.$ ed.). Glendale, CA: Pyrczak Publishing.

[33] Michael, S., Dittus, P., \& Epstein, J. (2007). Family and community involvement in schools: Results from the school health policies and programs study 2006. Journal of School
Health, 77(8), 567-587.

doi:10.1111/j.1746-1561.2007.00236.x

[34] Reynolds, A. J. (1991). Comparing measures of parental involvement and their effects on academic achievement. Early Childhood Research Quarterly, 7(3), 441-462.

[35] Rosenberg, H., \& Lopez, M. E. (2010, April). Family engagement from cradle to career. Family Involvement Network of Educators (FINE) Newsletter, 2(1). Retrieved from http://www.hfrp.org/publications-resources/browse-our-publi cations/family-engagement-from-cradle-to-career

[36] Shaw, C. A. (2008). A study of the relationship of parental involvement to student achievement in a Pennsylvania career and technology center. (Unpublished doctoral dissertation). The Pennsylvania State University. State College, PA.

[37] SPSS Inc. (2011). SPSS Base 20.0 for Windows. IBM inc., Chicago, IL.

[38] Suizzo, M.-A., \& Soon, K. (2006). Parental academic socialization: Effects of home-based parental involvement on locus of control across U.S. ethnic groups. Educational Psychology, 26, 827-846.

[39] Tabachnick, B. G. \& Fidell, L. S., (2007). Using multivariate statistics (5th ed.). Boston, MA: Pearson/ Allyn \& Bacon

[40] Yıldırım, A. ve Şimșek, H. (2005). Sosyal Bilimlerde Nitel Araştırma Yöntemleri (5. Baskı). Ankara: Seçkin Yayıncılık.

\footnotetext{
${ }^{i}$ The study is supported by Balikesir University: BAP Project No: 2015/001
} 